
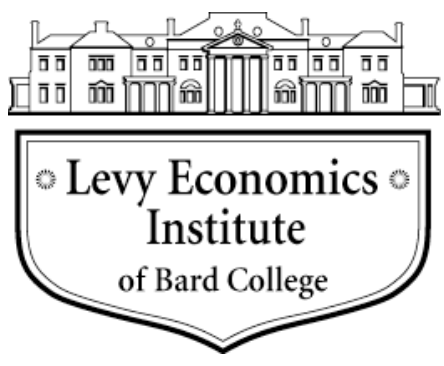

Working Paper No. 601

\title{
Too Big to Fail in Financial Crisis: Motives, Countermeasures, and Prospects
}

\author{
by
}

\section{Bernard Shull}

Professor Emeritus, Hunter College, CUNY

Special Consultant, National Economic Research Associates

June 2010

The Levy Economics Institute Working Paper Collection presents research in progress by Levy Institute scholars and conference participants. The purpose of the series is to disseminate ideas to and elicit comments from academics and professionals.

Levy Economics Institute of Bard College, founded in 1986, is a nonprofit, nonpartisan, independently funded research organization devoted to public service. Through scholarship and economic research it generates viable, effective public policy responses to important economic problems that profoundly affect the quality of life in the United States and abroad.

Levy Economics Institute

P.O. Box 5000

Annandale-on-Hudson, NY 12504-5000

http://www.levyinstitute.org 


\section{ABSTRACT}

Regulatory forbearance and government financial support for the largest U.S. financial companies during the crisis of 2007-09 highlighted a "too big to fail” problem that has existed for decades. As in the past, effects on competition and moral hazard were seen as outweighed by the threat of failures that would undermine the financial system and the economy. As in the past, current legislative reforms promise to prevent a reoccurrence.

This paper proceeds on the view that a better understanding of why too-big-to-fail policies have persisted will provide a stronger basis for developing effective reforms. After a review of experience in the United States over the last 40 years, it considers a number of possible motives. The explicit rationale of regulatory authorities has been to stem a systemic threat to the financial system and the economy resulting from interconnections and contagion, and/or to assure the continuation of financial services in particular localities or regions. It has been contended, however, that such threats have been exaggerated, and that forbearance and bailouts have been motivated by the "career interests" of regulators. Finally, it has been suggested that existing large financial firms are preserved because they serve a public interest independent of the systemic threat of failure they pose-they constitute a "national resource."

Each of these motives indicates a different type of reform necessary to contain too-big-tofail policies. They are not, however, mutually exclusive, and may all be operative simultaneously. Concerns about the stability of the financial system dominate current legislative proposals; these would strengthen supervision and regulation. Other kinds of reform, including limits on regulatory discretion, would be needed to contain “career interest” motivations. If, however, existing financial companies are viewed as serving a unique public purpose, then improved supervision and regulation would not effectively preclude bailouts should a large financial company be on the brink of failure. Nor would limits on discretion be binding.

To address this motivation, a structural solution is necessary. Breakups through divestiture, perhaps encompassing specific lines of activity, would distribute the "public interest" among a larger group of companies than the handful that currently hold a disproportionate and growing concentration of financial resources. The result would be that no one company, or even a few, would appear to be irreplaceable. Neither economies of scale nor scope appear to offset 
the advantages of size reduction for the largest financial companies. At a minimum, bank merger policy that has, over the last several decades, facilitated their growth should be reformed so as to contain their continued absolute and relative growth. An appendix to the paper provides a review of bank merger policy and proposals for revision.

Keywords: Too Big to Fail; Banking Policy; Antitrust; Government Policy; Regulation

JEL Classifications: G21; G28 


\section{INTRODUCTION}

The free market system is fueled by the success and failure of firms in a multitude of industries. The exit of firms that fail as a result of market developments or managerial mistakes is as much a cornerstone of growth and efficiency as innovation and easy entry. When government intercedes to keep failed firms alive, it undermines the system's foundations.

Banking, nevertheless, has long been treated differently. It has had the benefit of a safety net provided by the Federal Reserve and deposit insurance, supplemented by extensive supervision and regulation. For close to 40 years, however, “deregulation” has permitted banks to become more like other kinds of firms, with a broader set of permissible activities, the elimination of geographic restrictions, and relatively free entry. Exit for large banking companies, however, has remained a remnant of the past. Exceptional government support for stockholders and/or uninsured creditors of most banks was abandoned after passage of the Federal Deposit Insurance Corporation Improvement Act of 1991—but not for large banks deemed too big to fail (TBTF).

During the financial crisis of 2007-09, government intervention forestalled the failure of the largest financial firms in the country. The troubling implications of these bailouts have generated numerous proposals to prevent a reoccurrence.

This paper considers proposed reforms within the context of earlier experience and the possible motives for government support for large failing banks. Section II provides a brief review of the bailouts in the crisis of 2007-09 and their likely long-term effects. Section III provides background in the experience of the last 40 years. Section IV considers a number of suggested motives for these policies. Section V evaluates the implications of differing motives for the efficacy of different types of reform. An appendix provides information on the rapid growth of large banking companies through merger over the last two decades and proposals for revisions in merger policy.

There are significant obstacles to containing too-big-to-fail policies. Large banks and other financial firms, perceived as posing a systemic threat, typically become exposed to market instability over long periods of growth. ${ }^{1}$ Even with improved supervision and regulation,

\footnotetext{
${ }^{1}$ See Minsky $(1957,1971)$.
} 
government support is likely. To paraphrase Hyman Minsky—“it can happen again.” But there is a better chance of dealing effectively with the problem if we have a better understanding of why it has been intractable. It is concluded that structural reforms to limit further increases (and, in fact, to reduce them) in concentration among the largest financial companies would be useful.

\section{TOO BIG TO FAIL IN FINANCIAL CRISIS}

Government support for the largest financial companies in the country during the crisis of 200709 was multidimensional. In addition to traditional monetary ease, as well as an extension of and increase in deposit insurance, it included substantial Treasury investments in large banking companies, an unprecedented expansion of discount window credit, with the Federal Reserve (Fed) establishing an array of new programs to inject funds into specific financial markets, along with the purchase of the direct obligations of FNMA and FMAC, and financing mergers of large failed banks into other large banks. During the crisis, major investment and finance companies became bank holding companies to avail themselves of Federal Reserve credit. ${ }^{2}$ The result of this extraordinary assistance was to sustain, with a few exceptions, the largest financial firms in the country. ${ }^{3}$ The explicit intention was to avert a perceived threat to the financial system and the economy. Moral hazard and anticompetitive side effects were recognized, but discounted. ${ }^{4}$

\section{AN INTRACTABLE PROBLEM}

Over the last four decades, legislative and regulatory modifications have failed to contain TBTF policies. Any number of pronouncements have been made, alternately expressing frustration as to bailouts of financial firms and confidence in reform. Following the collapse of Continental

\footnotetext{
${ }^{2}$ These included Goldman Sachs, Morgan Stanley, and American Express, among others.

${ }^{3}$ The principal exceptions included the IndyMac F.S.B., an earlier spin-off from Countrywide Financial Corporation, that failed in July 2008, and Lehman Brothers, which went into bankruptcy in September 2008. Bear Stearns was acquired by J.P. Morgan-Chase with the help of financing by the Federal Reserve Bank of New York; Wachovia was acquired by Wells Fargo; Merrill Lynch and Countrywide Financial were acquired by the Bank of America. Fannie Mae and Freddie Mac were placed in government conservatorship, but have continued to function. ${ }^{4}$ Market identification of financial companies TBTF makes possible low-cost funding that provides a competitive advantage, facilitates oligopolistic behavior, and encourages greater risk-taking. For a model of dynamic limit pricing with mutual forbearance in local banking markets that derives from the emergence of a small group of national/global banking companies with a presence in concentrated local/regional markets populated by a fringe group of smaller banks, see Shull and Hanweck (2001: $161 \mathrm{ff}$.
} 
Illinois, one of the largest banks in the country at the time, Congressman Fernand St. Germain expressed the frustration:

"[Continental Illinois is] an institution that failed to survive without massive, record breaking, infusions of Federal moneys and credit. Deja vu. For a decade and a half [we]...have probed bank and regulatory failures....[W]e battled uphill ...to enact an entire set of new and improved supervisory powers-to make certain that no one in the Federal supervisory bureaucracy could claim they lacked the tools. Yet, today, we return to this forum... the granddaddy of bank failures... rolled into the ditch uncontrolled...." 5

In introducing a new restructuring of supervision and regulation in 1989, the Financial Institutions Reform, Recovery, and Enforcement Act (FIRREA), after a decade of savings and loan insolvencies, the Secretary of the Treasury, Nicholas Brady expressed the confidence: "Two watch words guided us as we undertook to solve this problem-Never Again.”6

\section{A. Experience since the 1970s}

The 1960s and 1970s were a transition period in banking, from a highly regulated system established in the 1930s to a relatively deregulated system. In the course of the transition, bank failures increased. The Fed, the Federal Deposit Insurance Corporation (FDIC), and/or the Comptroller of the Currency (OCC) typically supported failed or failing banks in one way or another.

“Open bank assistance” was provided by the FDIC on the determination that a bank was essential to its community. ${ }^{7}$ Used sporadically until 1971, it extended such assistance more regularly thereafter. ${ }^{8}$ The FDIC has indicated that it was aware that its assistance had harmful side effects. It asserted that it used its authority “...sparingly, because it was concerned that the

\footnotetext{
${ }^{5}$ Fernand St. Germain, Inquiry into Continental Illinois Corp. and Continental Illinois National Bank (1984: 1).

${ }^{6}$ Brady (1989).

${ }^{7}$ Section 13(c) of the Federal Deposit Insurance Act of 1950. For a detailed description of FDIC authority to support failed and failing banks, see FDIC (1998: vol. 1, part 1, ch. 2).

${ }^{8}$ In 1971, it provided "open bank assistance” to the floundering Unity Bank in Boston and, through the 1970s, to a number of other banks. Some of the better known were the Bank of the Commonwealth of Detroit (1972), the American Bank and Trust of Orangeburg, South Carolina (1974), Farmers Bank the State of Delaware (1976), and First Pennsylvania, the largest bank in Philadelphia at the time.
} 
assistance would benefit stockholders, materially erode market discipline, and keep afloat a weakened bank to the possible detriment of the local community." 9

The FDIC was not sparing in its support in cases where banks were not deemed “essential.” By arranging for a healthy bank to purchase the assets and assume all the liabilities of a failed bank, (a "P\&A" transaction), ${ }^{10}$ as opposed to simply paying-off insured depositors (a “payoff”), it was uncommon through the 1980s for uninsured depositors of any failed commercial bank to suffer losses. ${ }^{11}$ The FDIC justified this approach as a way to "level the playing field” for smaller banks that had to compete with large banks that were TBTF.

The Federal Reserve provided assistance to failing banks as a lender of last resort. In 1974, for example, it extended a substantial volume of credit to Franklin National Bank through its discount window that delayed its closing and afforded its uninsured creditors time to withdraw their funds. ${ }^{12}$

The quintessential TBTF case, however, occurred in 1984 when Continental Illinois National Bank faced a run in the wake of rumors about bad loans. The FDIC, the Fed, and the OCC saw the pending collapse of Continental as a threat to a large number of smaller banks whose funds it held, as well as to other large banks whose uninsured creditors might quickly withdraw their funds if the Continental's creditors experienced losses. The banking agencies coordinated support that included an assurance by the FDIC that all uninsured creditors of the Bank and its affiliates would be protected, and provided a large infusion of funds to augment Continental's capital. ${ }^{13}$ The Comptroller of the Currency testified, at the time, that the eleven largest banks in the Unites States were too big to fail. ${ }^{14}$

\footnotetext{
${ }^{9}$ FDIC (1998: vol. 1, part 2, p. 519).

${ }^{10}$ Because liabilities of the failed bank exceeded the value of its assets, the "P\&A" transaction might require a payment by the FDIC to the acquiring bank. However, acquiring banks were frequently willing to include in their bids a premium for the "franchise" or "charter value" of the failed bank.

${ }^{11}$ Section 13(e) of the FDI Act allowed the FDIC to provide financial assistance to facilitate the absorption of a failing bank by another institution. However, it proceeded under the requirement that the cost incurred in the P\&A transaction did not exceed the cost of a "payoff." A “payoff” would leave the amounts returned to uninsured depositors subject to the liquidation process.

${ }^{12}$ For a discussion of the Franklin National case, other financial problems in the 1960s and 1970's, and Federal Reserve policies, see Minsky (1982: ch. 2). For additional information on many of the major bank failures of this period, see Sprague (1986) and Hetzel (1991).

${ }^{13}$ See Isaac (1984: $457 \mathrm{ff}$.).

${ }^{14}$ He identified these as BankAmerica, Bankers Trust, Chase Manhattan, Chemical Bank, Citibank, Continental Illinois, First Chicago, J.P. Morgan, Manufacturers Hanover Trust, Security Pacific, and Wells Fargo.
} 
In the late 1980s, the FDIC also extended guarantees to all uninsured depositors of the Bank of New England (BNE) suffering from losses on real estate loans and to two affiliated banks. The justification was that continued operation of these three banks was "essential" to provide adequate depository services in their respective communities. ${ }^{15}$ BNE and its affiliates were ultimately taken over by the FDIC and sold to Fleet/Norstar Financial Group. ${ }^{16}$ In this case, a Government Accounting Office report asserted that the OCC had repeatedly muted criticism of the bank and limited the scope of its examinations. The Comptroller acknowledged deficiencies in supervision and promised "to prevent similar problems from occurring again." ${ }^{17}$

About the same time, Citibank also experienced serious problems stemming from real estate loans and foreign debt. With major borrowers declaring bankruptcy, its debt was downgraded by the credit rating agencies. In July 1991, Representative John Dingell of Michigan announced that the bank was "technically insolvent." ${ }^{, 18}$ His assertion was disputed by William Seidman, then Chairman of the FDIC. Whether “insolvent” or not, Citibank's actual capital level was inadequate. The OCC decision not to close the bank can be characterized as forbearance.

\section{B. FIRREA and FDICIA}

Concern about the insolvency of large numbers of savings and loan institutions (S\&Ls), and commercial banks in the 1980s and early 1990s led to passage of FIRREA in 1989 and the FDIC Improvement Act (FDICIA) in 1991. ${ }^{19}$ Among other things, these laws strengthened supervision and regulation with the aim of limiting forbearance and bailouts.

FIRREA mandated capital requirements for S\&Ls no less stringent than those for national banks. It curtailed S\&L activities deemed risky, and more so for what it labeled

\footnotetext{
${ }^{15}$ The affiliates were the Connecticut Bank \& Trust Company of Hartford, CT, and Maine National Bank of Portland, ME.

${ }^{16}$ The FDIC established bridge banks and ultimately reached a P\&A agreement with Fleet for all three banks. See FDIC (1998: Vol. I, Part II, Ch. 8).

${ }^{17}$ Gerth (1991).

${ }^{18}$ The statement, which was made in "Hearing" before Subcommittee on Telecommunication and Finance of the House Energy and Commerce Committee, was widely reported. See Quint (1991).

${ }^{19}$ For a review of these problems and data on numbers of failures and assets of failed banks over the 1980s, see National Commission on Financial Institution Reform, Recovery, and Enforcement, June (1993); Randall (1989: 324); and Barth, Brumbaugh, and Litan (1992: 29-54).
} 
"troubled institutions. ${ }^{20}$ FDICIA elaborated the "troubled institution" approach of FIRREA, by establishing a new capital rating system requiring federal bank regulators to escalate their intervention as capital levels dropped ("prompt corrective action"). ${ }^{21}$

FDIC assistance to uninsured creditors of failed banks through P\&A transactions was terminated. FDICIA required the FDIC to resolve failed banks by the method least costly to the insurance fund, replacing the old standard that permitted a P\&A transaction if it was less costly than a payoff. Even if a P\&A transaction that covered uninsured depositors was less costly than a "payoff," it would always be more expensive than having the acquiring bank assume only insured deposits. The law also limited the FDIC's ability to provide "open bank assistance" for "essential” institutions. These restrictions were coupled with constraints on Federal Reserve loans to undercapitalized institutions. ${ }^{22}$

FDICIA, however, did provide an exception for banks whose failure posed a systemic threat. It provided that the FDIC's "least cost” standard could be abandoned through a joint determination with the Federal Reserve and the Secretary of the Treasury (with agreement by the President) that compliance would have seriously adverse effects on economic conditions or financial stability (systemic risk exception). And "open bank assistance” could be authorized. ${ }^{23}$

At best, FIRREA and FDICIA made a continuation of "too big to fail" policy uncertain.

Their lack of success became clear in 1998 when the Federal Reserve prevented the immediate closure of the hedge fund Long-Term Capital Management out of concern for the solvency of large financial institutions to which it was indebted. It organized a group of creditors to recapitalize the firm. Fed Chairman, Alan Greenspan stated that the impact on moral hazard was

\footnotetext{
${ }^{20}$ See Shull (1995: 585-612). Among other things, it prohibited "troubled institutions" from accepting brokered deposits, offering above-market interest rates on deposits, and increasing assets. Activities viewed as excessively risky, such as the holding of junk bonds, were prohibited. Equity investments were limited.

${ }^{21}$ A determination that a bank was not "well" or "adequately" capitalized was to trigger supervisory restrictions. Banks in the lower classifications were to submit an acceptable capital restoration plan. Banks in the lowest classification, "critically undercapitalized," were to be promptly closed. The law specified a terminal requirement of tangible equity-to-total-assets of 2 percent for "critically undercapitalized" institutions. FDICIA also authorized the FDIC to establish deposit insurance premiums on a risk-adjusted basis and a new capital rating system that was applicable both to commercial banks and savings associations. Building, in part, on the Basle agreement on riskadjusted capital requirements (1988), it mandated that the agencies provide uniform rules for capital classifications that included "interest rate risk," "concentration risk," and "non-traditional activity risk."

${ }^{22}$ In addition to restrictions on extending credit to institutions not certified as "viable" by a primary Federal regulator or by the Fed Chairman, the law provided that the Fed would incur a liability to the FDIC if it did lend and a subsequent failure imposed a cost on the deposit insurance fund.

${ }^{23}$ The FDIC would have to determine that the bank's management was competent, had complied with applicable laws, and that there was no "insider abuse."
} 
more than offset by the disaster in financial markets that would have occurred had Long-Term Capital Management been forced into sudden bankruptcy. ${ }^{24}$

\section{WHY AREN'T LARGE FINANCIAL COMPANIES PERMITTED TO FAIL?}

That banks are vulnerable to runs that could cause panics and economic distress was the basis for the Federal Reserve Act of 1913 and federal deposit insurance in the 1930s. The moral hazard issue made both controversial when first established. ${ }^{25}$ Now generally accepted, this Federal safety net added a macro-prudential rationale for regulation and supervision. ${ }^{26}$

Following the massive bank failures of the 1930s, regulatory restrictions on competition and risk-taking implied that all banks were too important to fail. In contrast, deregulation that got underway in the 1960s proceeded on the assumption that bank failure could be tolerated.

The largest banks have been an exception. The explicit justification by bank regulators (and Congress) for bailing out large financial firms has been to forestall systemic threats. Some have questioned this justification, suggesting that bank regulators have tended to exaggerate. For example, a post-bailout analysis of Continental Illinois found that closing the bank without the FDIC protections for uninsured creditors would not have resulted in the failure of many other banks. $^{27}$

The “exaggeration” charge is consistent with the observation that bank regulators have covered-up problems and have been sluggish in closing insolvent banks. It has been argued that they are motivated by personal gain in the form of career advancement and the retention of

\footnotetext{
${ }^{24} E x$ ante, the Greenspan decision standard might be stated as follows: the expected cost (weighted probability) of disaster was greater than expected benefits of reducing moral hazard. This might be true even if the probability of financial collapse was relatively low. See also GAO, Long-Term Capital Management, Report GAO/GGD-00-3, October (1999) and Lowenstein (2000: 194-195, 229 ff.).

${ }^{25}$ See Smith (1936). Even Bagehot, who argued the need for the Bank of England to serve as a lender of last resort, understood that doing so constituted a departure from free market principles and encouraged financial institutions to take on increased risk. For early criticism of Treasury intervention in panics, see Andrew (1907: 560). For early criticism of deposit insurance, see Laughlin (1908) and Roosevelt (1932).

${ }^{26}$ For a brief but careful discussion of the moral hazard created by the lender-of-last-resort safety net, see Bryant (1984: 22 ff).

${ }^{27}$ Stern and Feldman (2004: 48-49).
} 
influence. ${ }^{28}$ If true, their behavior would constitute a type of malfeasance linked to complaints about the political influence of large financial institutions.

Exaggerated concerns about systemic risk, sluggishness in closing large failing banks, and seemingly unjustified bailouts can reflect yet another motive - that is, the belief that large financial companies serve a public interest. In Japan and other southeast Asian countries where large banks provide a mechanism for the allocation of resources, there is evidence that this motive is important. ${ }^{29}$ Absent central planning or industrial policy, and during a period in which large financial firms have been severely criticized, this motive may not seem applicable in the United States. But there is a long historical record of public purposes served by large banks.

In the 1984 Hearings on Continental Illinois, Congressman Frank Annunzio articulated one kind of "public interest" defense for the bailout:

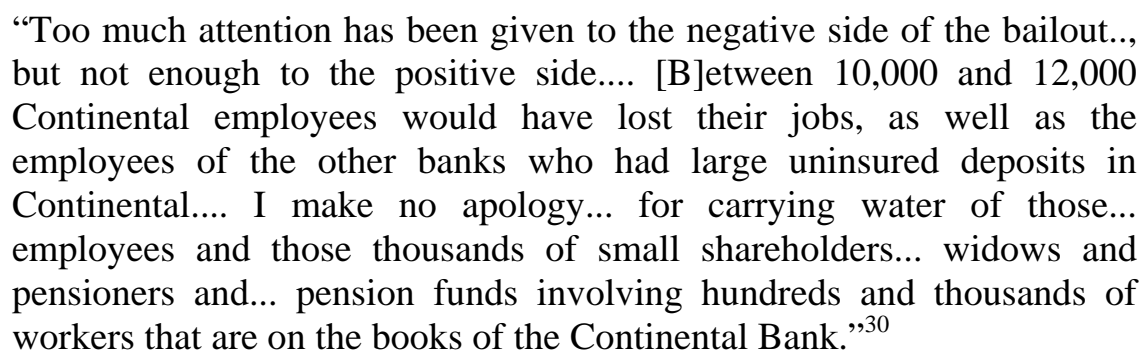

In the same Hearings, Congressman Jim Leach asked the Comptroller of the Currency, C. T. Conover, if Continental could be liquidated at no cost to anyone, would there be "a loss to society?” Could one argue, he continued "on size grounds... to save something that is truly important, a national resource" (italics added). ${ }^{31}$ Large banking companies have, in recent years, been defended on the grounds that they operate efficiently, not only to meet the global financial needs of their large corporate customers, but to help integrate world financial markets and promote economic growth in developing countries. ${ }^{32}$

\footnotetext{
${ }^{28}$ Edward Kane has been the principal proponent of this view. For an evaluation of the analysis, see Stern and Feldman (2004: 51 ff.).

${ }^{29}$ Stern and Feldman (2004: 56-58).

${ }^{30}$ Annunzio (1984: 80-81).

${ }^{31}$ Inquiry into Continental Illinois Corp. and Continental Illinois National Bank (1984: 373). The Comptroller replied: "No, we never thought Continental was important as a national resource." It is not clear from the record whether Leach accepted this answer.

${ }^{32}$ For an elaboration of this view, see Calomiris (2009).
} 
This "national resource" motivation for forbearance and bailouts merits further consideration. It has deep historic roots. Public service was a well understood obligation of the first banks chartered in the United States; they were modeled on the 17th-18th century Bank of England, "a private firm employed as a public agent."33 The bank-government relationship was on-going and involved various quid pro quos, including government support for banks in difficulty.

The Bank of England itself provided an early example of what this meant. After being chartered to extend credit to the government, as well as to operate as a private bank, it faced a run in 1696 and was forced to suspend cash payments, but it had the support of the Treasury. Charles Montagu, Chancellor of the Exchequer, wrote: “...the bank notwithstanding all the hardships... are yet resolved to venture all for the Government and I hope what they do in our distress will not be forgotten in theirs....” John Houblon, the first Governor of the Bank of England, told his shareholders that Lords of the Treasury had indicated that “...neither the Government nor the trade of England can be carried on without creditt, and that they know if the creditt of the Bank be not maintained, no other creditt can be supported." ${ }^{34}$ In only its second year of existence, the Bank of England was TBTF.

Similar stories can be related about early American banks. A hundred years after the Bank of England withstood a run, the Bank of New York found it could not pay its debt to the First Bank of the United States. At the request of Alexander Hamilton, Treasury Secretary Oliver Wolcott intervened to secure forbearance. Wolcott sensibly expressed a concern that still resonates. "These institutions have all been mismanaged; I look upon them with terror. They are at present the curse, and I fear they will prove the ruin of the Government." ${ }^{35}$ In 1796, the Bank of New York was also TBTF.

Perhaps the oldest recorded case that illuminated the "public purpose" motive for support involved the Jewish court bankers of the 10th century Abbasid Caliphate. The bankers were subject to intense pressure to provide funds to the government. It was surprising to scholars that

\footnotetext{
${ }^{33}$ See Shull (1983).

${ }^{34}$ The description of events and quotations are from Clapham (1945: 39-50).

${ }^{35}$ Wolcott's letter of December 8, 1796 is reprinted in Syrett (1974: 435-436). An earlier call for help to the Treasury by the Bank of New York, as a result of specie withdrawals, is reported in Hammond (1957: 84). Another early request for Treasury help by a Pennsylvania bank is described in Holdsworth (1910: 67-68).
} 
they survived as long as they did. ${ }^{36}$ The explanation was found in an early 10 th century document:

The bankers "...were never dismissed..; to uphold the dignity of the office... so that the merchants might... lend through the... jahbadh [banker].... Were a jahbadh to be dismissed and another appointed... with whom the merchants had not yet had any dealings, the business of the Caliph would come to a standstill., ${ }^{37}$

These bankers were also TBTF.

That this kind of symbiotic relationship between government and large banks is still relevant was evidenced in 1982, when Mexico was unable to service its debt and had begun to suffer a flight of capital. The crisis threatened the largest American banks, to which Mexico was indebted, and the stability of Mexico itself, as well as other Western Hemisphere countries. Paul Volcker, then Chairman of the Federal Reserve Board, engineered a rescue. ${ }^{38}$ He secured loans from national and international governmental agencies and persuaded the banks to exercise forbearance. When the crisis was resolved, he extolled the "community of interest among borrowers and lenders, among governments and private businesses...”39

Shortly thereafter, Secretary of the Treasury Donald Regan defended a request to Congress for an additional \$8.5 billion to the International Monetary Fund that would help repay the debt of developing countries to large American banks.

"There is a widespread concern that [this]... will amount to a bail-out of banks at the expense of American taxpayers. Many would contend... that they've dug themselves... into this hole through greed and incompetence.... Errors in judgment were made, and excesses on the part of both borrowers and lenders are now evident.... But we should not ignore the fact that the banks performed an invaluable function during the 1970s in taking primary responsibility for recycling the OPEC surpluses to deficit nations. Had the banks not performed this task, the strains on the international financial system would have been much greater and the amount of official financing from governments, including the United States, would have far exceeded the amounts now being sought." 40

\footnotetext{
${ }^{36}$ Fischel (1937: 23, 32-33).

${ }^{37}$ Nishwar al-Muhadara, in Fischel (1937: 28-29).

${ }^{38}$ For relevant details, see Kraft (1984). For a brief review and additional references, see Shull (2005: 149-152).

${ }^{39}$ As quoted in Kraft (1984: 49).

${ }^{40}$ Regan (1983: 17).
} 
Secretary Regan was probably unaware that he was channeling the sentiments of Charles Montagu in 1696: “... I hope what they do in our distress will not be forgotten in theirs....”41

It can be briefly noted that this motivation is consistent with other legislative and policy developments over the last quarter-of-a-century, including the systemic risk exception in FDICIA, the relaxed bank merger policy over the last 25 years that facilitated the growth of the largest banks, the merger of large failing banks into large floundering banks during the crisis of 2007-09, and government bail outs of automobile, aircraft, and other nonbanking firms whose failure did not constitute a systemic threat, but whose survival was deemed to have public value.

\section{MOTIVES AND COUNTERMEASURES}

The effectiveness of specific measures to deal with the problems raised by TBTF policies depends on the motivation(s) for regulatory forbearance and bailouts. As noted, however, the several motives are not mutually exclusive and may all need to be addressed.

If the motivation is to forestall systemic threat, then measures that aim at the prevention of bank failure are in order. Reforms would include risk-constraining regulation and more rigorous supervision, possibly augmented by new approaches to "market discipline" and new techniques for quickly closing failed banks. These types of reforms have been debated over the years and have been the focus of legislation now under consideration in Congress. ${ }^{42}$ How well they succeed remains to be seen. ${ }^{43}$

If banking problems were only the product of inept, imprudent, or dishonest managers, then better supervision and regulation might be fully effective in eradicating failures. But experience and analysis indicates that the principal cause of banking problems have been macro-

\footnotetext{
${ }^{41}$ Paul Krugman (2009) recently commented on another aspect of the on-going bank-government relationship. With respect to the fate of Bear Sterns in the recent crisis, he observed that: " $[\mathrm{m}]$ ajor financial firms are a small club, with shared interest... Furthermore, big financial firms have a long-term relationship, both with the government and with each other, and can pay a price if they act selfishly in times of crisis. Bear Stearns... earned itself a lot of ill will by refusing to participate in that 1998 rescue [of Long-Term Capital Management], and it's widely believed that this ill will played a major factor in the demise of Bear Sterns itself....”

${ }^{42}$ See Restoring American Financial Stability Act of 2010 and Wall Street Reform and Consumer Protection Act of 2009. Proposals for fortifying market discipline through additional disclosure and the issuance of subordinated debentures have been discussed for more than 15 years. See Stern and Feldman (2004: ch. 13, appx. D).

${ }^{43}$ For a discussion of additional issues that suggest current reform may not be effective, see Kregel (2009).
} 
economic processes that periodically turn good managers into bad ones. ${ }^{44}$ Recurring shocks to the system and financial instability are to be expected, as is banks becoming fragile over long periods of prosperity.

If, in such circumstances, forbearance and bailouts derive from exaggerated claims of systemic threat, whether the product of honest miscalculation or private career interests, supervisory and regulatory reforms will prove ineffective. Measures that penalize the regulatory authorities for miscalculation or misdeeds, restrict discretion, and alter incentives would be in order. $^{45}$

Finally, if forbearance and bailouts reflect an implicit contract that accepts the largest financial companies as having a survival value in the public interest, then all of the above reforms would prove futile. The remedy would be structural; that is, to distribute the public interest among a larger group of banking firms than the handful in which there currently exists a disproportionate and growing concentration of financial resources, so that no one or few would be perceived as irreplaceable.

To this end, there have been recent proposals to break-up the largest companies. Wellknown financial authorities have argued that "if they're too big to fail, they're too big." Mervyn King, Governor of the Bank of England, has said that "[i]t is in our collective interest to reduce the dependence of so many households and businesses on so few institutions that engage in so many risky activities."47

There is precedent in the United States for judicious divestitures. Antitrust decisions dismembered nonfinancial companies such as Standard Oil in 1911, Alcoa in 1945, and AT\&T in 1983. In 1933, the Glass-Steagall Act forced financial firms to choose between accepting deposits and dealing in securities. J.P. Morgan split into Morgan Guaranty and Morgan Stanley; First Boston Corporation separated from First National Bank of Boston. In some cases, affiliates surrendered their banking charters and liquidated their assets; in others they separated from parent banks and continued as independent firms.

\footnotetext{
${ }^{44}$ See, for example, Minsky (1971, 1982).

${ }^{45}$ For some proposals in this respect, see Stern and Feldman (2004: 58-59 and appendix B).

${ }^{46}$ This group includes former Fed chairman, Alan Greenspan and former Secretary of the Treasury, George Schultz. See McKee and Lanman (2009).

${ }^{47}$ Wessel (2009: A2).
} 
The Bank Holding Company Act of 1956 also forced divestitures. Under its provisions, registered bank holding companies (those controlling two or more banks) were prohibited from controlling almost all nonbanking firms. Their permissible activities, narrowly interpreted by the Fed, were to be of a "financial, fiduciary, or insurance nature" that was "closely related to the business of banking....” Transamerica, which controlled a large number of commercial banks in western states as well as other affiliates engaged in activities such as insurance, real estate, fish packing, and oil development, made a decision to withdraw from banking.

One type of break-up suggested would restore Glass-Steagall Act restrictions that were eliminated by the Gramm-Leach-Blyley Act of 1999 (GLB). ${ }^{48}$ To fully separate commercial banking from investment banking, and other kinds of financial and non-financial activities, additional restrictions would be necessary. Prior to the 1999 Act, commercial banks had been able to expand into investment banking, insurance, and other activities through interpretation of existing law by the Federal bank regulatory agencies. ${ }^{49}$

The wisdom of restoring commercial banking to Glass-Steagall Act status has been disputed, ${ }^{50}$ but it would be reasonable to restrict further growth by closing some of the avenues for activity expansion that GLB permits. ${ }^{51}$ Early Fed and the Treasury proposals and rulings under GLB implied an interaction between the old standard for activity expansion ("closely related to banking") and the new standard for financial holding companies ("financial in nature") that implied a dynamic expansion of permissible activities into both financial and commercial activities, possibly to the point where conglomerates like Transamerica, before the 1956 Holding Company Act could be put together.

\footnotetext{
${ }^{48}$ The Glass-Steagall sections of the Banking Act of 1933 were 16, 20, 21, and 32. Sec. 16 limited bank dealing and underwriting to specified types of securities: i.e., obligations of the United States and general obligations of states and political subdivisions. Sec. 20 prohibited banks from having affiliates principally engaged in dealing in securities. Sec. 21 prohibited firms dealing in securities from accepting deposits. Sec. 32 prohibited interlocks of directors and officers of securities firms and banks. The Gramm-Leach-Blyley Act repealed Sections 20 and 32.

${ }^{49}$ Beginning in the 1980s, the Fed interpreted the term "principally engaged" in Section 20 to permit holding company affiliates to underwrite otherwise impermissible securities. The OCC had permitted national banks to engage in otherwise impermissible activities, including insurance activities, through "special operating subsidiaries" if it was determined that they were "incidental" to "the business of banking." Glass-Steagall Act restrictions did not apply to state-chartered non-Federal Reserve- member banks..

${ }^{50}$ For reasons why it is impractical to restore the Glass-Steagall Act provisions separating commercial from investment banking, see Kregel (2010).

${ }^{51}$ For an analysis of the mechanisms for activity expansion under GLB, see Shull (2002).
} 
The "Volcker rule" that would prohibit proprietary trading, as well as sponsoring of and investing in hedge funds and private equity funds is an example of selective activity prohibition. It is not directly aimed at size and concentration, but it could be viewed as contributing to restraints on increases in both. To that end, a careful review of activities made possible by GLB (e.g., real estate brokerage and management) to select an activity that has been controversial, might be undertaken to assess the benefits and costs, including the cost of augmenting the size of banks currently too big to fail. It is notable that GLB does not require a net public benefits test for entry into activities determined to be "financial in nature."

Additional constraints on activity expansion may slow the growth of the largest companies somewhat. A revision of bank merger policy would slow growth further. As discussed in the appendix, bank merger policy, that for close to a half-century has incorporated antitrust standards, has ignored TBTF issues. ${ }^{52}$ The policy should be revised to require the Federal bank regulatory agencies, when reviewing mergers, to consider the competitive and soundness issues raised by the harmful effects of TBTF. It should be possible, through a revision of bank merger policy, to prevent the further concentration of financial resources in a handful of companies and, over time, to reduce it.

Activity and merger restrictions will help, but not, in themselves, solve the problem. Further break-ups of large banking companies may be possible without adverse side effect on efficiency. As shown in the appendix, the largest have grown through mega-mergers over the past two decades. Any break up might begin with unwinding some of the more recent mergers that were approved without any consideration given to TBTF.

It is important to note that neither merger nor activity restrictions, nor even more radical break-ups of the existing large financial companies, need result in any significant loss in economic efficiency. After decades of research, a consensus has emerged among economists to the effect that economies of scale are exhausted at well below the size of the largest banks and economies of scope deriving from their diversification are difficult to find. ${ }^{53}$

\footnotetext{
${ }^{52}$ White (2009).

${ }^{53}$ For a recent review of the literature, see Scherer (2010). For an earlier review, see Shull and Hanweck (2001: 133135 and 151-155). Despite declarations of improved efficiency by banks proposing mergers, the evidence is, at best, mixed (Rhoades 1998).
} 


\section{CONCLUSIONS}

The bailout of almost every major financial company in the United States in the course of the financial crisis of 2007-09, coupled with efforts to eliminate such bailouts over the last 40 years, has made clear that TBTF is an intractable problem. The moral hazard and competitive side effects of bailouts are unacceptable, yet when large banks are in dire straits they appear unavoidable.

The persistence of TBTF policies in the face of supervisory and regulatory reforms and the possible exaggeration of systemic threats, raise questions as to the motives of the authorities. A better understanding of the rationale(s) for TBTF policies throws light on why they have been so difficult to contain and the kind of reforms that might be effective.

In addition to the justification that forbearance and bailouts are necessary to forestall systemic threats, it has been argued that authorities pursue such policies for personal gain. Still another rationale may derive from a long-standing bank-government relationship that finds public value in the continued functioning of the largest financial firms. These several motives are not mutually exclusive, but they have differing implications for effective reform.

Current legislative proposals have focused on moderating systemic risk through modifications to supervision and regulation, and new approaches to resolving large bank failures. The emergence of a few very large companies in which financial resources are concentrated raises questions as to whether this approach alone will be effective. Limiting further growth through restrictions on specific activities, revisions of bank merger policy, and possibly divestiture to reduce concentration provides some hope for containing TBTF problems. Proposals to revise policy are suggested.

Whatever the motivation for forbearance and bailouts, it is risky to have a relatively few large banking institutions in which a large proportion of financial resources are concentrated. Each, by virtue of its absolute and relative size, would be system-threatening in failure, each would unavoidably exercise powerful influence over regulatory authorities, and each would likely be viewed as an irreplaceable "national resource.” 


\section{REFERENCES}

Andrew, A. Piatt. 1907. “The Treasury and the Banks under Secretary Shaw.” Quarterly Journal of Economics 21(August): 529-569.

Annunzio, Frank. 1984. in Inquiry into Continental Illinois Corp. and Continental Illinois National Bank, Sept. 18: 80-81.

Barth, James., E.D. Brumbaugh, Jr., and R.E. Litan. 1992. The Future of American Banking. Armonk, NY: M.E. Sharpe, Inc.

Brady, Nicholas. 1989. “Statement.” Treasury News, February 6.

Bryant, Ralph C. 1984. Eurocurrency Banking: Alarmist Concerns and Genuine Issues. Washington, DC: The Brookings Institution.

Calomiris, Charles. 2009. "In the World of Banks, Bigger Can Be Better.” Op Ed, Wall Street Journal, October 29.

Clapham, John. 1945. The Bank of England: A History, Vol. I. London: P.S. King \& Sons.

FDIC. 1998. Managing the Crisis: The FDIC and RTC Experience, 1980-1994, Vols. 1 and 2. Washington, DC: FDIC.

Fischel, Walter. 1937. The Jew in the Economic and Political Life of Mediaeval Islam. London: Royal Asiatic Society.

Gerth, Jeff. 1991. "Study Sees Lax Bank Regulation.” The New York Times, Business Section, September 17.

Government Accounting Office. 1999. Long-Term Capital Management. Report GAO/GGD-003, October.

Hammond, Bray. 1957. Banks and Politics in America. Princeton, NJ: Princeton University Press.

Hetzel, Robert L. 1991. “To Big to Fail: Origins, Consequences, and Outlook.” Economic Review, Federal Reserve Bank of Richmond 77(6): 3-15.

Holdsworth, J.T, and D.R. Dewey. 1910. The First and Second Banks of the United States, National Monetary Commission, 61st Cong., 2d Sess., Doc. No. 571. Washington, DC: U.S. Government Printing Office. 
Inquiry into Continental Illinois Corp. and Continental Illinois National Bank. 1984. "Hearings” before House Committee on Banking, Finance and Urban Affairs, 98th Cong., 2d Sess., Sept. 18 and 19, and October 4.

Isaac, William M. 1984. “Statement.” in Inquiry into Continental Illinois Corp. and Continental Illinois National Bank, October 4, pp. 457, ff.

Kraft, Joseph. 1984. The Mexican Rescue. New York: The Group of Thirty.

Kregel, Jan. 2010. “No Going Back: Whey We Cannot Restore Glass-Steagall’s Segregation of Banking and Finance.” Public Policy Brief, No. 107.

Kregel, Jan. 2009. “Observations on the Problem of 'Too Big To Fail/Save/Resolve'.” Policy Note. Annandale-on-Hudson, NY: Levy Economics Institute of Bard College.

Krugman, Paul. 2009. “Op-Ed.” New York Times, Nov. 20.

Laughlin, J. Laurence. 1908. “Guarantee of Bank Deposits.” Address to the State Bankers’ Association of Nebraska, Lincoln, Nebraska, September 25 (unpublished).

Lowenstein, Roger. 2000. When Genius Failed. New York: Random House.

Minsky, Hyman P. 1982. "Finance and Profits: The Changing Nature of American Business Cycles.” as reprinted in Minsky, Can It Happen Again? Armonk, NY; M. E. Sharpe 1982.

Minsky, Hyman P. 1971. “Financial Instability Revisited.” Reappraisal of the Federal Reserve Discount Mechanism, Vol. 3, Federal Reserve Board.

Minsky, Hyman P. 1957. “Central Banking and Money Market Changes.” Quarterly Journal of Economics LXXI(2).

McKee, Michael, and Scott Lanman. 2009. “Greenspan Says U.S. Should Consider Breaking Up Large Banks.” Bloomberg.com, October 15.

National Commission on Financial Institution Reform, Recovery and Enforcement. 1993.

Origins \& Causes of the S\&L Debacle: A Blueprint for Reform, A Report to the President and the Congress of the United States. Washington, DC, June.

Quint, Michael. 1991. “Business Section.” New York Times, August 1.

Randall, Richard E. 1989. “Can the Market Evaluate Asset Quality Exposure in Banks?” New England Economic Review, Federal Reserve Bank of Boston, July/August: 3-24. 
Regan, Donald T. 1983. "Statement.” Foreign Assistance and Related Programs Appropriations for 1984, Part 6, Hearings before a Subcommittee of the House Committee on Appropriations, 98th Cong., 1st Sess., Sept. 15.

Restoring American Financial Stability Act of 2010. Committee on Banking, Housing and Urban Affairs, U.S. Senate, S3217.

Rhoades, Stephen A. 1998. “The Efficiency Effects of Bank Mergers: An Overview of Case Studies of Nine Mergers.” Journal of Banking and Finance 22: 273-291.

Romer, Paul. 2009. New York Times, February 6: A13.

Roosevelt, Franklin D. 1932. “Letter.” New York Sun, October.

Scherer, F.M. 2010. “A Perplexed Economist Confronts 'Too Big To Fail’.” Working Paper, RWP 10-007. Cambridge, MA: Harvard Kennedy School.

Shull, Bernard. 1995. “The Limits of Prudential Supervision.” Economic Notes 24(3): 585-612.

Shull, Bernard. 1983. “The Separation of Banking and Commerce: Origin, Development and Implications for Antitrust.” The Antitrust Bulletin 28(1): 255-279.

Shull, Bernard. 2005. The Fourth Branch: The Federal Reserve's Unlikely Rise to Power and Influence. Westport, CT: Praeger.

Shull, Bernard. 2002. "Banking, Commerce and Competition under the Gramm-Leach-Blyley Act.” The Antitrust Bulletin, Spring.

Shull, Bernard, and Gerald Hanweck. 2001. Bank Mergers in a Deregulated Environment. Westport, CT: Quorum Press.

Smith, Vera C. 1936. The Rationale of Central Banking. London: P.S. King \& Sons.

Sprague, Irvine H. 1986. Bailout. New York: Basic Books.

Stern, Gary H., and Ron J. Feldman. 2004. Too Big To Fail. Washington, DC: Brookings Institution Press.

Syrett, Harold C. (ed.). 1962. The Papers of Alexander Hamilton, Vol. III. New York: Columbia University Press.

Wall Street Reform and Consumer Protection Act of 2009. U.S. House Financial Service Committee, H.R. 4173. 
Wessel, David. 2009. “Three Theories on Solving the 'Too Big To Fail’ Problem.” The Wall Street Journal, October 28.

White, Lawrence J. 2009. "Financial Regulation and the Current Crisis." Paper presented to the a Symposium on Competition and Public Policy, Antitrust Section of the American Bar Association, May 13-14 (revised, June 2009). 


\section{APPENDIX A}

\section{BANK MERGER POLICY}

Originally designed to restrain concentration and the rapid growth of large banks, bank merger policy has, over the last several decades, facilitated mergers and acquisitions by the largest banking companies and substantially increased concentration. Growing in absolute and relative size, a number have emerged as clearly posing a systemic threat.

Between 1980 and 2009, there were well over 10,000 mergers (table 1). The number of independent commercial banking organizations was cut in half, declining from about 12,000 to about 6,000 (table 2).

The most notable structural change has been the increase in national concentration. Over this period, the deposits held by the 5 largest commercial banking organizations in the United States increased from about 12 percent to 43 percent (table 3). The top five became the top four with the Wells Fargo acquisition of Wachovia in 2008.

Since 1991, the four largest grew substantially through large acquisitions of banks whose size reached into the many hundreds of billions. Over this period, the modern Bank of America, the largest banking company in the country today, materialized out of 18 such large mergers. The modern Wells Fargo was forged in 12, JP Morgan Chase in 7, and Citigroup in 3, including the massive combination of CitiCorp and Travelers (table 4).

Every merger and acquisition that contributed to this structural transformation was first reviewed and approved by a Federal bank regulatory agency (the Comptroller of the Currency, the Federal Reserve, or FDIC). Since the early 1960s, these agencies have evaluated the competitive effects of each proposal under the provisions of the Bank Merger and Holding Company Acts. Competitive review typically focuses on the projected impact in one or more local markets and is based on current antitrust standards. The Justice Department provides the banking agencies with an advisory memorandum in each case; it retains jurisdiction over bank mergers under the antitrust laws.

Even before competitive issues came within the domain of the banking agencies, they had the responsibility to consider the effects of bank mergers on "the convenience and needs of the community," the "financial condition" of the banks, and "prospects"-the so-called "banking 
factors.” None of the federal banking agencies have ever considered the too-big-to-fail issue in any merger evaluations.

Large banks have typically merged through holding companies. The Federal Reserve has primary authority over holding company combinations. While its evaluations of both holding company and bank mergers resulted in a number of important denials in the 1960s and the early 1970s, since the mid-1980s, there have been few denials and none of large bank combinations. ${ }^{1}$

There have been several reasons for these developments:

(1) Changes in the banking environment. Liberalization of branching and activity restrictions permitted geographic- and product-market expansion, thereby enabling freer entry and more potential competition.

(2) Improved analytical techniques. A revision of the Justice Department's "Merger Guidelines" provided a better basis for bank market determination that tended to expand markets and thereby reduce concentration levels.

(3) Changes in the Federal Reserve's approach to merger review. Most importantly, the Federal Reserve established a new approach in the 1980s that effectively made possible the approval of all large bank mergers. It provisionally accepted Justice Department's "Guidelines" as to the impact of a proposed merger on local market concentration. If the Guideline levels were violated by the proposed merger, the Board would negotiate concentration-reducing divestitures. If these did not fully correct the problem, it would consider "mitigating factors" as offsets. These mitigating factors included:

\footnotetext{
${ }^{1}$ The rare denial on competitive grounds by the Federal Reserve has typically been a small bank combination in a rural market. The last one was BancSecurity Corp of Mashalltown, IA (\$415 million deposits) to acquire Marshalltown Financial Corp. (\$103 million in deposits) in 1996. The geographic market was determined to be rural Marshall County plus a few other adjacent areas. The merger would have caused the Herfindalh-Hirschman Index (HHI) to increase 849 points to 3032, well in excess of the Justice Department's acceptable standards. The Justice Department has not been in court with a bank merger case since 1987. Its last suit was in the mid-1980s. The last court decision was in1987 (U. S. v Central State Bank, 621 F. Supp. 1276).
} 
(a) the continued presence of potential competitors;

(b) the existence of a substantial number of banks remaining in the market; and

(c) improvements in efficiency.

The elimination of interstate branching restrictions by the Riegle-Neal Act after 1994 expanded the pool of potential competitors in most metropolitan area markets. The continued operations of small banks in the market was similarly viewed as an offset to higher concentration, even when they constituted a "fringe" group in a market dominated by one or two major banking firms. The extent to which claims of improvements in efficiency were accepted is difficult to determine. As noted above, a general consensus had developed after decades of research that economies of scale were exhausted at bank sizes well below that of the largest banks and there was little evidence of economies of scope. In a unique study by Rhoades of postmerger changes in efficiency in nine cases, he found, at best, mixed evidence of gains. ${ }^{2}$ The mergers selected for study were ones that were most likely, a priori, to improve efficiency. All resulted in significant cost cutting, but only four resulted in actual cost efficiency gains. No identifiable factors could be cited as causing improved efficiency gains, not even condition whereby one of the merging banks was clearly more efficient than the other.

The new approach permitted the Federal Reserve largely to offset effects on local market concentration in approving mergers. In 1997, it approved a merger of the largest bank in Columbus, $\mathrm{OH}$, with about 61 percent of market deposits, to acquire the second largest bank in the market with about 19 percent. It did require divestitures that notably restrained the increase in the leading bank's market share to about 64 percent. ${ }^{3}$ The approval, nevertheless, increased bank concentration in a local market that was more than double the level that the Justice Department viewed as "highly concentrated." Approvals such as this, and others, ${ }^{4}$ raised questions as to whether the Federal Reserve, which in earlier years had been the most aggressive Federal agency in constraining bank mergers, would ever deny another one. In fact, since 1996, it has not. ${ }^{5}$

\footnotetext{
${ }^{2}$ Rhoades (1992)

${ }^{3}$ Southern National Corporation, 83 Fed. Res. Bull., 596, 598 and Dissent, 602 (1997).

${ }^{4}$ The Board's approval of the merger of NationsBank Corp and Barnett Banks, Inc. in 1997 raised similar questions in several Florida markets. See NationsBank Corp 84 Fed. Res. Bull. 130-35 (1998).

${ }^{5}$ Some Board members and the Board's staff have, nevertheless, suggested that a number of proposed mergers have been discouraged in informal discussions prior to the submission of applications.
} 
Throughout their thousands of merger reviews, as mentioned, neither the Federal Reserve, nor any other Federal banking agency, nor, for that matter, the Justice Department, has ever considered the anticompetitive implications of establishing or augmenting a banking organization too big to fail. Nor have they ever considered the systemic threat possibilities as a "banking factor."

At least one revision in merger and related policies was proposed about a decade ago, aimed at constraining large banking firms likely to be too big to fail. ${ }^{6}$ The proposals remain relevant and should be an element in any program that aims to keep the TBTF problem from getting worse. They include:

\section{(1) A more complete analysis of each merger proposal by the Federal Reserve and other}

banking agencies. Mitigating factors have facilitated large bank mergers with adverse consequences. The addition of aggravating factors would serve as a counterweight. These should include:

Establishment or augmentation of a bank TBTF and related considerations, such as: (a) the effect of the merger on market dominance by merged organization; (b) evidence of reduced competitive effectiveness of the banks remaining in the market; and (c) the impact of the merger on the likelihood of intermarket coordination between the merged banks and other large banks.

(2) Amend the Riegle-Neal Act. This 1994 Act now prohibits mergers where the resulting bank will have 10 percent or more of national deposits or 30 percent or more of a state's deposits. These limits should provide for progressively increasing negative weights in merger cases as 10 percent and 30 percent limits are approached. If aggregate concentration has anticompetitive and/or other adverse effects they are likely to develop incrementally, not suddenly above a specific limit—one that, in any event, can be avoided through the shifting of deposits.

(3) Restrict negotiated divestitures. Bar divestiture agreements where one or both of the merging banks is already "too big to fail” or will become so as result of merger. Divestiture agreements have, by reducing projected local market concentration, enabled large bank mergers that have

\footnotetext{
${ }^{6}$ These proposals, in more detail, can be found in Shull and Hanweck (2001: ch. 6).
} 
created and augmented such banks, thus sacrificing the anticompetitive and systemic risk consequences of too big to fail on the altar of local market concentration.

\section{(4) Impose higher capital requirements and deposit insurance premiums on large banks. On}

determination by a federal banking agency that the insolvency of a banking organization is likely to present as systemic threat, its capital requirements and deposit insurance premiums should be raised to approximate the costs to other banking firms not similarly supported. The aim is to moderate advantages and perverse incentives that flow from the likelihood of government support that reduces funding costs, expands borrowing capacity, creates incentive for greater risk taking, encourages additional mergers, and promotes anticompetitive behavior.

\section{(5) Require annual reports to congress on banking and financial structure. The federal} banking agencies and the Justice Department should provide annual reports to Congress, with public hearings, on banking structure and competition, comparable to the monetary reports now provided by the Federal Reserve. Reports should include: merger policy developments, changes in banking and financial structure, evaluation of competitive issues created by developments, current practices and policies, and expectations for coming year.

The need for continuing congressional oversight of developing banking structure as managed by federal banking agencies and Justice Department in their merger decisions became apparent in the crisis of 2007-09. The TBTF problem is structural and ongoing in periods of prosperity, as well as in periods of financial crisis. The competitive and bail-out issues are two sides of the same coin. 


\section{APPENDIX B: TABLES}

\section{Table 1. Numbers of Mergers, 1980-2009}

Bank Mergers..........10,787

Large Bank Mergers....583

Mega-bank Mergers.......64

Notes: Mergers include combinations of thrift institutions with commercial banks Large Mergers" are defined as mergers in which organization had $\$ 1$ billion or more in assets.

"Mega-bank-mergers" defined as mergers in which each organization had \$10 billion or more in assets.

Source: Adapted from data in Stephen A. Rhoades (1995) "Bank Mergers and Industry-wide Structure, 1980-94.” Staff Study, Board of Governors of the Federal Reserve System. Updated and revised data have been obtained from the Financial Structure Section Board of Governors of the Federal Reserve System. 
Table 2. Structural Change-National, 1980-2006

\section{Structural Characteristic}

No. of insured US commercial banks

No. of banking organizations

No. of banking offices
1980

2006

2009

14,407

12,342

7,321

6,228

82,442

6,770

5,944

52,710

N/A

Source: Adapted from data in Stephen A. Rhoades (2005) "Bank Mergers and Industry-wide Structure, 1980-94” Staff Study, Board of Governors of the Federal Reserve System. Updated and revised data have been obtained from the Financial Structure Section Board of Governors of the Federal Reserve System. 


\title{
Table 3. Aggregate Concentration Consolidated for Organizations
}

\author{
(Percent of Deposits)
}

Concentration

Held by top 5

Held by top 10

Held by top 25

Held by top 100
1980

2006

35.9

45.1

60.0

74.3

11.9

18.6

29.1

46.8
2009
42.5

52.0

65.6

77.3

Source: Adapted from data in Stephen A. Rhoades (2005) “Bank Mergers and Industry-wide Structure, 1980-94” Staff Study, Board of Governors of the Federal Reserve System.Updated and revised data have been obtained from the Financial Structure Section Board of Governors of the Federal Reserve System. Concentration data is consolidated for banking organizations, i.e., all holding company bank subsidiaries, and relates to consolidated bank holding companies + unaffiliated, independent banks. 
Table 4. Merger Lineage of the Four Largest Domestic Banking Organizations* (principal mergers, 1991$2008^{* *}$, in billions of dollars)

\section{Banking Organization}

Bank of America Corp.

JPMorgan Chase Co.

CitiGroup

Wells Fargo \& Co.
Total Assets (12/31/2009)

$\$ 2,252.814$

$\$ 2,041.009$

$\$ 1,888.599$

$\$ 1,228.652$

\section{Acquisitions (Assets)}

1991: Nations Bank a. C\&S/Sovereign (\$51.4)

1991: Fleet Financial Group a. Bank of New England (\$13.4)

1992: Bank America a. Security Pacific (\$76.4)

1993: Nations Bank a. MNC (\$17.0)

1994: Bank America a. Continental (\$22.6)

1995: Fleet Financial a. Shawmut (\$32.7)

1996: Fleet Financial a. National Westminster (\$430.1)

1996: Bank of Boston a. Bay Banks (\$12.1)

1997: Nations Bank a. Barnett (\$44.7)

1997: Nations Bank a. Boatmen’s (\$41.8)

1998: Nations Bank a. Bank America (\$265) (Bank of America)

1999: Fleet Boston a. Bank Boston Corp (\$50.7)

2002: Fleet Boston a. Summit Bancorp (\$39.9)

2004: Bank of American a. Fleet Boston (\$203.2)

2007: Bank of America a. LaSalle Bank Corp (\$115.7)

2007: Bank of America a. U.S. Trust Corp (\$10.5)

2008: Bank of America a. Countrywide Financial Corp. (\$121.4)

2008: Bank of America a. Merrill Lynch (\$875.0)

1991: Chase Manhattan a. Manufacturers Hanover (\$38.4)

1993: Bank One a. Valley National (\$11.5)

1996: Chemical a. Chase Manhattan (\$121)

2000: Chase Man. a. Morgan \& Co. (\$73.8) (JPMorgan Chase)

2004: JPMorgan Chase a. Bank One (\$328.8)

2008: JPMorgan Chase a. Washington Mutual Inc. (\$353.1)

2008: JPMorgan Chase a. Bear Sterns (\$350e)

1998: Travelers (\$420.0) a. Citicorp (\$331) (CitiGroup)

2001: CitiGroup a. European American (\$15.0)

2002: CitiGroup a. Golden State Bancorp (\$50.7)

1991: First Union a. Southeast $(\$ 13,390)$

1995: First Union a. First Fidelity (\$35.7)

1996: Core States a. Meridian (\$15.3)

1996: Wells Fargo a. First Interstate (\$58.1)

1998: Norwest a. Wells Fargo (\$93.2) (Wells Fargo)

1998: First Union a. Core States (\$46.9)

2000: Wells Fargo a. First Security Corp (\$21.4)

2001: First Union a. Wachovia (\$70.6) (Wachovia)

2004: Wachovia a. South Trust (\$53.7)

2006: Wachovia a. Golden West Financial Corp. (\$144.5)

2006: Wachovia a. Westcorp (\$15.9)

2008: Wells Fargo a. Wachovia Corp (\$772.6)

*In 1991, the largest 5 Domestic Banking Organizations in the United States held 16 percent of commercial banking assets in US. In 2009 they held close to 42.5 percent. In 2008, the "Big 5" became the "Big 4" when Wells Fargo acquired Wachovia. The 5th largest bank holding company is now Goldman Sachs $(\$ 882,586.0)$ followed by Morgan Stanley and Met Life.

** All Acquisitions are of organizations with $\$ 10$ billion or more in assets.

Source: Board of Governors, Federal Reserve System (Financial Structure Section). See also Stephen Pilloff, Bank Merger Activity in the United States, 1994-2003, Staff Study No. 176, May 2004, p. 9, Table 7. Total assets for 12/31/09 from FFIEC, National Information Center, "Total Assets of Top 50 Bank Holding Companies." 